\title{
Realizing the Horn of Africa in a New Context: Challenges and Opportunities for Peace in Somalia
}

\author{
Liban Abdullah
}

\begin{abstract}
In 1991 growing political pressure and infighting led to the collapse of the Somalia government. Key institutions of governance disintegrated, and public services could no longer be provided. The Somali National Army was amongst the key institutions that collapsed and, in its place, warlords and clan militias emerged to fill the gap. Henceforth for over two decades, these non-state actors competed over control of both political and economic power while other radical organizations such as Al-Shaabab emerged with an objective to establish an Islamic state. This instability thus led to displacement of populations, insecurity both at the domestic and regional level. This thesis seeks to examine how the collapse of Somali impacted the military and why moving forward in the transitional period, reforming the military is vital to the future of Somalia and geopolitical and economic stability. The thesis adopts state building and realism as it theoretical frameworks and argues for the need of military reforms within the conceptual frameworks of security reforms. Specifically, the thesis reiterated that if the Horn of Africa and the greater Eastern Africa region is to experience geopolitical and economic stability, then the SNA should undertake key reforms in order to reinforce its capacity to resolve domestic instability in Somalia which is the causal factor in geopolitical and economic instability caused by threats such as terrorism, piracy, and bilateral tensions between regional states. The study suggests that reforms in the military such institutional capacity building, coordination of security assistance, and establishing civilian oversight over military is critical in reviving the capacity of SNA and with it, the first step towards restoring regional stability.
\end{abstract}

Keywords: Security Sector, Military Reform, Institutional and Capacity building, Somali National Army, Security Sector Reform

\section{Introduction}

One of the fundamental justification for the existence of states is to provide and guarantee the peace and security of its citizens and the state itself. In those states that have experienced damage of their sovereignty because of unprecedented factors such as the complete collapse of government and other institutional structures, they not only lose their capacity to safeguard sovereignty and territorial integrity but also protect citizens. To restore the capacity of the state to provide security and establish stability, sustainable peace, and good governance, then security sector reforms becomes a critical component of peace building and state-building. Security sector reforms provides a framework for the demobilisation and integration of armed non-state actors such as militia groups, establishment of rule of law, and development of a comprehensive and sustainable system of security governance (Schnabel and Farr 2012).

However, a security sector reform in this context has proved to be elusive in Somalia. Since the collapse of the central government in 1991, the subsequent complex conflicts involving clan militias, the Somali National Army, and terrorist groups such as al-Shaabab have undermined the processes of security sector reforms. Over the course of three decades in which Somalia has experienced deep instability, non-state actors have gained so much influence that any attempts to conduct security sector reforms by either the federal government or international community requires the input of all the stakeholders in Somali's security sectors (Nyadera at al.2019). This is because the security landscape is so much redistributed and is epitomised by the existence of multiple actors.

When the government by Said Barre was overthrown in 1991, what followed was the disintegration of crucial institutions that sustain governance and demographic alterations in Somalia. The absence of a functioning central government rendered the state at the mercy of warlords who began to violently scramble for control of state assets both in the urban centres and in the rural areas that were under their spheres of influence. Events that surround the months between 1991 and 1992 were so devastating displacing over 1.5 million people and leaving 25000 others dead (Healy and Bradbury 2010). Although the people who witnessed the disintegration of the state describe it as burbur ('catastrophe'), what the conflict has done to the Horn of African country nearly three decades is captured on the Failed State Index (Foreign Policy 2008 -2011) where Somalia was the top country (Daniels 2012; Hansen 2013; Makinda 1999). Since then, the conflict has transformed from a civil war to a complex mixture of terrorism, piracy and sectarian violence. The impact of the crisis is no longer affecting the people of Somalia alone, but new threats have emerged threatening even regional countries. This comes on the background of a region whose member countries have yet managed to satisfactorily solve other pressing challenges such as disease, poverty, unemployment, low levels of literacy and underdeveloped infrastructure.

According to a report by the World Bank (October 27, 2020), insecurity has had a significant impact on Somalia and that ongoing security reforms aimed at securing Somalia had been and will continue to be expensive. According to the Report, the federal government of Somalia had spent approximately one-third (USD 197 million) of its budget on security sector reforms and that eight-out-of-10 government employees (accounting for 48 percent of government wage bill) were also found with the security sector. Other international partners in the form of international institutions and bilateral partners had also spent over USD 1.5 billion annually on Somalia's security sector. Indeed, such support without the government being able to develop its own capacity to restore stability is unsustainable. The federal 
government has equally taken these dynamics with great concern and has thus prioritised the establishing an acceptable, affordable, and accountable security sector as part of the far-reaching security sector reform strategy.

Regardless of the necessity of security reforms, several factors pose as challenges to the process. First, there are institutional challenges that compete with the federal government over the exercise of the monopoly of violence. The regional administrations have particularly been reluctant in ceding power to the central government especially over the exercise of the instruments of violence. Secondly, there are also challenges of informal institutions involve in the governance of behaviour of persons engaged in the maintenance of peace and security from both the government as well as non-state actors. Thirdly, the existence of non-state actors that also compete and share the monopoly of violence with the state also pose a challenge to security sector reforms especially given that the state has had to contend working with militia groups and foreign forces in order to thwart the threats posed by al-Shaabab and Islamic State in Somalia (Mesfin and Beyene 2018).

These sort of realities facing Somalia reiterate the extent to which conducting security sector reforms can be successful. Importantly, they reiterate why alternative thinking is imperative in order to identify other opportunities that can be supported to overcome these realities and perhaps lay the foundation of a much stable future for the country. Such an alternative thinking needs to cut across issues pertaining the interactions between the federal government and federal member states, the relationships between militia groups and clans, the impacts of a fragmented political system characterised by inter and intra-clan competitions, and the general question of to what extent is it possible to satisfactorily restore the quality of monopoly of coercion to the federal government.

By recognising these challenges, this article seeks to examine the nature of security sector reforms, the challenges, and the opportunities. The author argues that the continued existence of the informal institutions and structures undermines the authority of the federal government in exercising its monopoly of coercion. This authority is not only challenged by the militia groups operating in Somalia, but also sanctioned international missions such as AMISOM. Secondly, the authors argues that there is an emphasis put by international actors in on internal reforms in the security sector than in supporting the federal government to regain control over territories occupied by militia groups and al-Shaabab. In other words, that without adequate show of force by the federal government in consolidating territorial control, then it is highly likely that internal reforms will not be adequate to help the federal government reinstate its legitimacy as a sovereign actor with the sole mandate of the monopoly of violence throughout the territorial boundaries of Somalia.

Understanding fragile states and security sector reforms The concept of fragile states and security sector reforms are part and parcel of a wider nexus of security and development which has been subject of sustained global debate since the end of the Cold War (Lambach 2006). In many ways, security and development cannot be pursued without the other because violent conflict is one of the leading causes of underdevelopment and instability as it brings about economic stagnation, and negatively impacts the social and political development of a state. Similarly, in a hyper-globalised world, the impact of instability in one particular state can also diffuse to other states, thus, elevating the whole domain of security from not only a national concern, but also a regional and international concern.

Since the collapse of the central government in 1991, there has been increased political and academic interests in the notion of fragile states (Agwanda and Asal 2020) which has feature greatly in the foreign policy and security discourses even though some of the international development agencies or scholars have also used the term 'failed states.' However, the underlying idea of either failed or fragile states is that it represents the inability of a government to undertake its core responsibilities that pertain to the effective control of territory, guaranteeing public safety and security, capacity to govern the use of public resources, and deliver basic public services such as healthcare, and education. This understanding is premised on Thomas Hobbes' conceptualisation of the modern state, that is, its identity and the expected role it is supposed to play in the society. As such, when a given state is categorised as being fragile, then such a normative identity is given relative to the ability of the states to fulfil its mandate which is to exercise its monopoly on the use of violence and provision of public services in exchange for loyalty and order from members constituting its citizenry (Lemay-Hebert 2019).

For countries emerging from a period of violent conflict, the capacity and capability of the state to provide security and public services is minimal. However, for Somalia, this is not only a common but rather a unique problem. This is because the fragmented political system of Somalia means that not only is the federal government ineffective, but also its legitimacy is in disrepute. Many other actors such as federal member states and non-state militia groups have challenged the authority of the government throughout Somalia. Consequently, the effectiveness and legitimacy of the federal government has been weakened and has put the state in a constant environment of sporadic conflict. Statebuilding occupies a central agenda in fragile states and that has often been a key priority of international actors who emphasize on laying the foundation for institutions that can improve the quality of governance, basic security, justice, and the delivery of social services. It is in this context that security sector reforms have emerged to occupy a key agenda in state-building in Somalia.

Although in academic discourses the concept of security sector reforms is relatively, its practice is not. In the postcolonial era, former imperial powers such as Britain, Italy, France and Germany maintained and propagated extensive military relations with their respective former colonies by providing weapons, financial assistance, and military training particularly during the Cold War era period. This security assistance significantly reduced in the post-Cold War era as Western states begun pursuing broader security and foreign policy objectives through defence cooperation 
(Y1lmaz and Agwanda 2021). In regions such as Eastern Europe, military support therefore became a tool used to pursue and advance foreign policy goals such as good governance and democracy through reforms such as establishing civilian oversight over the military. These developments marked the beginning of post-Cold War security sector reforms across Eastern Europe (Edmunds 2018) and parts of the African continent (Ansorg 2017).

Henceforth, security sector reforms have become one of the core elements of foreign assistance to states grappling with instability and weak institutions. International actors engaged in post-conflict state-building often provide assistance with the establishment of appropriate mechanisms and institutional structures that seek to support security and stability through more open and democratic means. With the domain of security, these reforms are modelled to align with the security needs of the states and citizens while at the same time ensuring that they do so in tandem with the norms of democratic governance and rule of law. According to Andersen (2006) these reforms encompass four thematic areas that include core security actors such as the military, presidential guards, intelligence agencies, police, paramilitaries, and gendarmeries; ii) security oversight and management that includes institutions such as the legislature, parliamentary select committees, foreign affairs, ministry of defence, national security council, traditional authority, and the executive branch of government; iii)justice and institutions of law enforcements such as the ombudsmen, criminal investigation division, office of public prosecutions, the judiciary, and the correctional services system; and lastly iv) the non-statutory security actors such as clan militias, political party militias, armed liberation movements, and private security groups or companies.

Perhaps more importantly is that despite the need for security reforms in fragile states, the role of external actors in the reform processes must only be limited to helping, supporting, and facilitating the processes. However, implementation of security sector reforms need to be driven by the local actors in order to develop a sense of national ownership of the processes and legitimise is as an embodiment of a national vision and strategy meant to restore a state to peace and stability. Moreover, in the absence of local inputs, it is unlikely if not impossible, for security sector reforms to achieve success without the commitment and input of local security stakeholders. As such donors should play a key role in supporting rather than leading reforms in the security sector.

\section{Contextualising the Somali National Army}

When Somalia became independent from the British and Italians in 1960, its national army as not as divided nor as ineffective as it became in the later years. Specifically, it was the ambitious and irredentist agenda of the government of Somalia during the regime of Siad Barrethat deep divisions begun to emerge especially after the defeat of Somalia during the 1977 Ogaden War. An attempt to reunify all territories occupied by ethnic Somalis in the Horn and East Africa region led to the invasion of Ethiopia- a traditional enemy to Somalia since the $16^{\text {th }}$ century. A big defeat in the war sparked an attempted coup in 1978 and although it was thwarted, President Barre embarked on personalization of the military by appointed military officers from his clan to the high ranks in the military and transferring those from other clans to the civil sector. This 'ethnicization' of the army laid the seeds that eventually led to the collapse of the central government in 1991 and with it, key institutions including the military.

At independence approximately 5000 military personnel constituted the SNA (Robinson 2019) of which 1000 were drawn from the Somaliland Scouts after independence of Somaliland from Italy; 300 from tribal police; 900 from Mobile Police; and 2000 new recruits and the rest drawn from the Somali Army (Onor 2016; Agyeman-Duah 1986).This force expanded significantly to over 14,000 in $1968,30,000$ by 1974 , and over 54,000 during the Ogaden war in 1977-1978 and thereafter until the collapse of government. Equally, expenditure for the military increased with the growth in military personnel from just below USD 11 million in 1969 to USD 160 million in 1982 before it declined again throughout the later decades as a result of instability. These expenditures excluded Soviet Union support to Somalia as it geared towards its war with Ethiopia (International Institute for Security Studies 1993). However, the United States exploited the breakdown of relations between Somalia and Soviet Union to establish bilateral relations with Somali. In exchange for the use of naval bases in Kismayo, Berbera, and Mogadishu by the US military, Somalia was allocated military aid through the March 1980 Facility Access Agreement. According to Gallik and Winstead (1995) Somali received military aid amounting to approximately USD 160 millionfrom Germany, France, Italy, China, and Libya.

After decades of violence and instability, new efforts emerged to establish an effective military for Somalia as part of a broader framework to restructure and stabilise the country as well as protect the citizens especially from the threat of al-Shaabab and also to provide a viable framework through which international peacekeeping forces under the Africa Union Mission in Somalia (AMISOM) could ultimately leave Somalia. The first effort was epitomised by the establishment of the Transitional National Government in 2000 which laid the foundation of a new army by recruiting former soldiers of the Siad Barre regime and freelance fighters who later transitioned into the new Transitional Federal Government created in 2004 (Mubarak 2014).In addition to the previous Siad Barre soldiers, TFG also recruited militias from Puntland and clan militias in the Johwar and Bay region (ibid). In addition to the recruitments to the SNA, the TFG also developed the Somali National Security and Stabilization Plan (NSSP) in 2006 as the main policy framework to support the partnership between the government and other international partners with the main objective of establishing a sustainable, and complimentary security sector that could meet the needs of Somalia during its transitional phase.

The contemporary structure of the SNA was however conceived in 2009 when a Joint Security Force constituted of approximately 3,000 TFG and 2,000 Alliance for the ReLiberation of Somalia (ARS) forces. Notably, the fighters from the ARS were mostly the militia wing of the Islamic Courts that had occupied and ruled over Mogadishu after 
defeating warlords in 2006. Collectively, the SNA was to be provided support by both bilateral members' states as well as international institutions such as the United Nations in order to build its capacity and re-establish stability as well as a responsive security sector that could meet the needs of Somalia. However, almost a decade since the establishment of the post-2008 SNA, the aspired objectives are yet to be achieved. Indeed, what has characterised the security sector include more difficulties in quantifying the precise number of military personnel of the SNA while the integration of the existing SNA soldiers into the broader multinational peacekeeping operations under AMISOM has remained difficult given that SNA troops have to be scrutinised individually before they can be verified and confirmed as ready for deployment as part of the AMISOM force. According to a study by Williams (2020), this verification process has been so much slow such that in seven months, an estimated 800 SNA troops had been verified and allocated an identification card by AMISOM.

However, more recent data indicate that the personnel capacity of the SNA has increased to approximately 18,700 soldiers and non-commissioned officers who are divided into three brigades constituted of more than 30 battalions and special unites such as the Danab infantry. In addition, the World Bank (2017) estimated that in order to effectively operationalise the security sector reforms, then about USD 140 million would be required. But of greater relevance is that this amount is ay less than the total amount that Somalia receives in foreign aid. The main question therefore becomes why has security sector reforms failed to take hold until now? The next section examines some of the key challenges to security sector reforms in Somalia.

\section{Obstacles against the SNA reforms}

Since the revival of the SNA in 2008, progress has been very slow despite substantive financial resources committed by international partners towards the process. However, this slow progress has been as a result of several factors. First, security sector reforms have been conducted under an environment of conflicting interests between a section of local security stakeholders and international partners. The participation of several international actors as Kenya, Ethiopia, US and Italy has for instance been primarily premised on the urgent need to defeat al-Shaabab and the Islamic State in Somalia and the revival of a unified state of Somalia. These priorities are however not held in commonality with the federal member states (Reno 2018). These divergent conflicts of interests are the outcome of a deeply fragmented and contested nature of clan politics that has been elusive to reconciliation for decades since the beginning of the civil war and the subsequent broken political system in which political elites themselves were benefitting from the status of insecurity in the country. In addition, most of the federal member states have tended not to prioritise the defeat of al-Shaabab and instead, have put more focus on the dealing with local clan and sub-clan power competitions.

Secondly, lack of proper coordination between international partners in Somalia have weakened the impacts of security sector reforms especially given that a majority of the programs, training, and doctrines advocated by some of the providers of security assistance have been relatively less compatible to the security needs of the country, and specifically, those of the Somali National Army. According to Hills (2014), the government in 2012 requested international partners who had developed several independent initiatives to coordinate their programmes and align them to the need of the SNA. This is even after the SNA had been a subject of receiving uncoordinated security assistance since the establishment of the Transitional National Government that was established in 2000. While other donors such as European Union and the UK to some extent attempted to coordinate their support, other donors such as Turkey, UAE, Kenya, and Ethiopia have often provided support in their independent capacities. In 2016, the establishment of the 'S6' was heralded as a critical step towards coordination of donor support by bringing together international partners such as US, UK, UN, UAE and EU. However, this agenda recorded limited success and was substituted by the Comprehensive Approach to Security which sort to streamline stabilisation efforts; facilitate AMISOM programmes; prevent extremism; build security institutions; and create an efficient system of donor programme coordination (London Somalia Conference Security Pact 2017). In general, the lack of coordination of donor initiatives manifested in issues such as the use of several languages such as Amharic, Swahili, Turkish, English, Arabic, and French in military training thus rendering overseas trainees with very divergent skills as well as military doctrines than those found back at home. Carstens (2013) noted that poor coordination contributed to lack of adequate supply of military equipment such as ammunitions and military training facilities.

Clan politics have been a key challenge towards achieving any form of sustainable and effective security reforms in Somalia because the decision-making processes by the political elites have tended to be influenced by clan factors rather than the national security interest of the country. In other words, the loyalty that political elites have towards their respective clans override that of a national interest which in this context, regards the establishment of an efficient, effective, and responsive national army. The contemporary nature of Somali clan politics emerged during Siad Barre's regime in which his attempts to consolidate power sparked an attempted coup in 1978 and divided the military along clan affiliations (Robinson and Matisek 2020).The impact of inter-clan competition in Somalia have had far-reaching impacts particularly in trying t0o establish a unified command for the SNA because both the highranking and 'foot-soldiers' continue to display loyalty to previous warlords and clans instead of the federal government. Additionally, majority of the battalions as well as military brigades have continued to be organised and operate around clan affiliations thus limiting any prospects for effective cooperation between them. Indeed, this was also one of the findings in a report by UNSOM in 2017 that observed that not only did clan conflicts prevent cooperation between different battalions of the same brigade, but also command of the units revolved around one particular leader of the same clan and if a commander was from a different clan, then command authority was limited. As a consequence, the element of clan identity remains a huge stumbling block to establishing a national army and the 
public perception of the national military being dominated by a single clan affects its legitimacy.

Conducting reforms while the military is involved in conflict with terrorist organisations such as the al-Shaabab and Islamic State in Somalia has made security sector reforms a major challenge in Somalia. In principle, security sector reforms are best conducted and have a better chance of success when the military is not engaged in conflict with other actors. The war itself has been used to mobilise soldiers and in this regard, pulling them out from their fields of operation against a capable adversary such as al-Shaabab for purposes of undergoing training is considered as a 'luxury' that the federal government cannot afford. Moreover, at a time when a common vision of a national security architecture for the country is lacking because of the existing differences between the federal government and federal member states, the applicability of the standard security sector reforms thus come under scrutiny. Reforming the security sector during conflict for example when both the federal government and AMISOM were fighting al-Shaabab for the control of Mogadishu created several challenges particularly in terms of availability of weapons and equipment supplies thereby making it an uphill task for TFG soldiers and AMISOM forces to conduct joint military operations. Outside areas such as Mogadishu, distribution of combatants over a large territory and even fewer troops have undermined the operational capacity of the SNA.

The history of as a Somalia collapsed state has posed great challenges in security sector reforms since the year 2000 when such efforts begun to attract great attention. This contextual legacy has created an imperfect environment through which security sector reforms can easily be achieved. This is because when the processes begun in 2000, establishing a national army while attempting to negotiate and similarly establish a federal government made it very difficult to engage in effective security reforms. Even after the establishment of the various federal governments, control over territory has been very limited and the capacity of the government to provide basic social services particularly between 2000-2012 was nearly zero thereby significantly undermining the existence and legitimacy of the transitional governments. In the post-2012 period, historical tensions between the federal government and the federal member states have similarly been sustained especially after the federal governments established independent links with other external partners who provide support to the forces under the control of federal member states. In addition, the prolonged incapacity of the federal government to establish effective and responsive institutions that correspond to the needs of the people has over the time reinforced the public perception that the federal government is incompatible and thus they need other alternatives. The lack of financial resources has been high as one of the key challenges to building the SNA, yet the federal government has consistently failed to establish reliable and effective financial institutions such as those responsible for the collection of revenue or a fully functional Central Bank. This has meant that many citizens are not tax compliant at least not to the federal government leading to low government revenues which also become embezzled as a result of elite corruption in Somalia (Sofe 2020). The presence of weak institutions is epitomized the preference of international partners to for instance, not use the Central Bank but instead use other institutions such as Pricewaterhouse Coopers to deal with the problems of illicit financial flows in the country.

\section{Filling the gaps and unlocking elusive peace}

From the previous discussion, it is evident that Somalia is dealing with very complex problems in its efforts to build a resilient, effective, efficient, responsive, and accountable security sector. Lacks of vision as a result of clan politics, resources, resistance to the reforms by different security stakeholders, poor coordination, and influence of international partners have directly and indirectly undermined the process. However, going forward it will be critical that the Somali security sector stakeholders who are involved in security sector reforms take advantage of the various opportunities that present themselves in order to push the SNA towards achieving self-operational capabilities and capacities. These opportunities can present themselves in terms of operational activities, institutional capacity-building, and support activities to the SNA.

First, most efforts should be put towards restoring the operational capabilities of SNA by identifying the critical territorial jurisdictions that should be under the under the control of the federal government. These territories include those that are under the control of both AMISOM forces and those under the occupation of non-state actors such as alShaabab. This is vital to rebuilding the SNA because it enables key towns, seaports, roads, and other national infrastructure to be gradually transferred back to the control of Somalia security agencies and institutions such as SNA and provide a viable framework for the AMISOM forces to develop a clear exit strategy. Equally, this progressive transfer of security roles to the SNA could also offer the military with an ideal opportunity to acquire more operational experience before the ultimate withdrawal of all other foreign security actors. Perhaps even more importantly, the presence of the SNA and its role in providing security in key towns and roads instead of the alShaabab and other clan militias could equally constitute an important phase of rebuilding the legitimacy of the SNA through activities that enhance its public image.

Secondly, focusing on the implementation of initiatives and programmes that enhance institutional capacity-building is an essential addition to the efforts of security sector reforms in Somalia, Over the years, several initiatives such as the National Security Architecture plan, and Operational Readiness Assessment (Oxford Analytica 2018) have been proposed with far-reaching recommendations on reforms on payroll, development of military policy and doctrine, restructuring of the civil service, recruitment and training of forces, and judicial reforms. These reforms are very vital if successful security sector reforms are to be achieved. For instance, civilian oversight of the military is a mandatory reform for the SNA. Indeed, it is vital for states to have strong armies to protect both its sovereignty and territorial integrity. However, there is also a legitimate danger that having a very powerful army could also pose a huge threat to civilian leadership especially in societies that are emerging from periods of conflicts or those that are involved 
in consolidation of democracy. The ability of the army to enjoy its symbolic status in the society, its greater political advantage relative to the executive, superior organisational structure, and monopoly over the use of arms can make the military less incentivised to obey civilian authority (Eldem 2019). As a consequence, for a fragile state like Somalia that finds itself in the early transitional phase of post-conflict peace building, incorporating structures that lay the foundation for a strong framework of military oversight constitutes one of the most vital developments in military reforms.

Remuneration of military personnel should be prioritized if successful security sector reforms are to be realized particularly with the Somali National Army. In the past, military personnel have alluded to the poor payment of salaries and stipends as well as embezzlement of troop wages by middlemen as well as resources meant for the budgetary allocation to uniforms, weapons, and rations. A frustration emerging from poor remuneration of military personnel only degrades their morale and undermines the ability of the SNA to secure a state that has been engulfed in just about three decades of civil war, jihadist war, and clan violence. As a consequence, it is important that international actors such as the AU and international donor partners work on a collective framework to support timely, adequate, and regular payment of troops until such a time that the federal government of Somalia becomes capable of taking over this role.

Although efforts such as increasing the operational capacity of the Somali National Army, building institutional capacity, and regular remuneration of soldiers have a direct role on the security reforms, other indirect support activities are equally vital. These non-security efforts include strengthening local governance, countering violent activities through community sensitization programmes, meditation of conflicts, reconciliation, and stabilisation. Collectively, these indirect efforts can enhance the conditions suitable for sustainable peace. More importantly, these are activities that should prioritize the input of local communities in order to not only reflect and take into account their needs, but also meet their needs.

\section{Conclusion}

The success or failure of security sector reforms in Somalia is so much dependent on Somalia than external actors even though they have a critical role to play. The corrosive political competitions at the national as well as at the level of federal member states have made it very difficult to reach a compromise that reflects the national interest of Somalia. The different and competing institutions and the divergent goals and interactions between local and foreign actors have significantly undermined any form of accelerated efforts that could lead to the efficient security sector reforms. Importantly, given that the various structures and institutions of power have an influence over how different groups as well as persons behave, and in turn contribute to their contestations with the federal government's monopoly of violence, achieving security sector reforms without a national consensus is likely to remain elusive. The clan and sub-clan contestations will continue to remain a hindrance to sustainable peace in Somalia especially in light of the local governance frameworks that have sustained the federal member states.

This means that more than never Somalia needs its leaders to weather through the temptations of amassing power for personal interests and instead commence mobilising the society towards a progressive vision that seeks to produce indigenous strategies that can improve the current status of the country by facilitating the development of social, economic, and political conditions that can nurture stability. For over a decade, international partners have pumped resources both material and financial in the security sector reform processes, yet peace remains elusive. Once again, this reiterates that it is only Somalia through its political leaders and citizens who can have the vital impact in reshaping the future of the country moving forward. Sustained efforts more than ever before should be channelled towards breaking the primordial ties and the pursuit of informed national policies that not only supports efforts to establish national peace, but also regional stability in the Horn and Eastern Africa region. Such a goal can only be achieved if the country genuinely contributes to reform its security sector reforms, re-embark on national development, renounce any illegitimate territorial claims, build its democratic structures, and seek to engage in regional security and economic development initiatives.

\section{References}

[1] Agwanda, B., \& Asal, U. Y. (2020). State fragility and post-conflict state-building: an analysis of South Sudan conflict (2013-2019). Güvenlik Bilimleri Dergisi, 9(1), 125-146.

[2] Agyeman-Duah, B. (1986). The US and Ethiopia: The politics of military assistance. Armed Forces \& Society, 12(2), 287-307.

[3] Ansorg, N. (2017). Security sector reform in Africa: Donor approaches versus local needs. Contemporary Security Policy, 38(1), 129-144.

[4] Bradbury, M., \& Healy, S. (2010). Endless war: A brief history of the Somali conflict. African Journal on Conflict Resolution, (21), 10-4.

[5] Carstens, R. (2013). Analog War: How to Rid Somalia of al-Shabab once and for All-In Six (Not-So) Easy Steps. Foreign Policy. com, 7.

[6] Daniels, C. L. (2012). Somali piracy and terrorism in the Horn of Africa (Vol. 1). Scarecrow press.

[7] Edmunds, T. (2018). Security sector reform in transforming societies: Croatia, Serbia and Montenegro. Manchester University Press.

[8] Gallik, D., \& Winstead, D. (1995). World Military Expenditures and Arms Transfers. Arms Control And Disarmament Agency Washington DC.

[9] Hansen, S. J. (2013). Al-Shabaab in Somalia: The history and ideology of a Militant Islamist group. Oxford University Press.

[10] Hills, A. (2014). Security sector or security arena? The evidence from Somalia. International Peacekeeping, 21(2), 165-180.

[11] International Institute for Strategic Studies. (1993). The Military Balance, 1993-1994. The Institute. 
[12] Lambach, D. (2006). Security, development and the Australian security discourse about failed states. Australian Journal of Political Science, 41(3), 407-418.

[13] Lemay-Hébert, N. (2019). State fragility and international recognition. In Routledge Handbook of State Recognition (pp. 306-315). Routledge.

[14] London Somalia Conference Security Pact.(11 May 2017). https://www.gov.uk/ government/publications/london-somalia-conference2017-security-pact

[15] Makinda, S. M. (1993). Seeking peace from chaos: humanitarian intervention in Somalia. Lynne Rienner.

[16] Mesfin, S., \& Beyene, A. D. (2018). The Practicalities of Living with Failed States. Dadalus, 147(1), 128140.

[17] Mubarak, M. (2014). Somali military has more problems than lack of guns. African Arguments, 28.

[18] Nyadera, I.N., Ahmed, M.S., Agwanda, B. (2019). Transformation of the Somali Civil-War And Reflections for a Social Contract Peacebuilding Process. Gaziantep University Journal of Social Sciences, 18(4), 1346-1366.

[19] Onor, K. C. (2016). United States Africa command and human security in Africa (Doctoral dissertation).

[20] Oxford Analytica (2018), "AMISOM's Somalia withdrawal will be long and difficult", Expert Briefings.https://doi.org/10.1108/OXAN-DB233901

[21] Schnabel, A., \& Farr, V. (Eds.). (2012). Back to the roots: Security sector reform and development. LIT Verlag Münster.

[22] Reno, W. (2018). The politics of security assistance in the horn of Africa. Defence Studies, 18(4), 498-513.

[23] Robinson, C. D. (2019). The Somali National Army: An Assessment. Defense \& Security Analysis, 35(2), 211-221.

[24] Robinson, C. D., \& Matisek, J. (2020). Assistance to Locally Appropriate Military Forces in Southern Somalia: Bypassing Mogadishu for Local Legitimacy. The RUSI Journal, 165(4), 68-78.

[25] Sofe, A. A. (2020). Assessment of corruption in the humanitarian assistance in Puntland State of Somalia. Journal of Financial Crime.

[26] UNSOM (January 2017)., Somalia Security and Justice Public Expenditure Review (Mogadishu: UNSOM).

[27] Williams, P. D. (2020). Building the Somali National Army: Anatomy of a failure, 2008-2018. Journal of Strategic Studies, 43(3), 366-391.

[28] World Bank. (2017). 'Summary Update: Security Public Expenditure Review, Somalia Comprehensive Approach to Security Conference, Mogadishu, December 2017.

[29] World Bank. (October 27 2020). Somalia Economic Update: Reforming Somalia's Security Sector: A Pathway to Increased Investment in Development Initiatives. Available

https://www.worldbank.org/en/country/somalia/public ation/somalia-economic-update-reforming-somaliassecurity-sector-a-pathway-to-increased-investment-indevelopment-initiatives Accessed on 17 July 2021.

[30] Wulf, H. (2004). Security sector reform in developing and transitional countries. Berghof Research Center for Constructive Conflict Management, 5.
[31] Y1lmaz, A.G.,\& Agwanda, B., (2021). Turkey's contribution to international policing, Global Change, Peace \& Security, 33:2, 143161, DOI: 10.1080/14781158.2021.1924128 